Renata Almeida Motta, et al., Int. J. Sus. Dev. Plann. Vol. 8, No. 3 (2013) 348-361

\title{
CRISIS OF PUBLIC TRANSPORT BY BUS IN DEVELOPING COUNTRIES: A CASE STUDY FROM BRAZIL
}

\author{
RENATA ALMEIDA MOTTA ${ }^{1}$, PAULO CESAR MARQUES DA SILVA ${ }^{1} \&$ \\ MARCIO PEIXOTO DE SEQUEIRA SANTOS ${ }^{2}$ \\ ${ }^{1}$ Transport Program, University of Brasília, Brazil. \\ ${ }^{2}$ Transport Engineering Program, Federal University of Rio de Janeiro, Brazil.
}

\begin{abstract}
This article discusses the problems faced by many developing countries in urban public transport by bus and suggests that most of their systems are in need of comprehensive rehabilitation and reform. It also indicates the imperative necessity of establishing priority for collective over individual transport in these countries. Besides, it analyzes the evolution of demand for urban bus service in Brazil, showing the reasons for its decline over the past 16 years, although it has stabilized somewhat recently. Trends regarding population aging, average income, unemployment rate, inflation, bus fare, fuels prices and several other indicators are examined to delineate measures that may help the demand for urban bus service in Brazil to grow, which can also benefit developing countries that may learn from Brazil's lessons.

Keywords: Brazil, crisis, demand, developing countries, mass transport, public transport, social exclusion, sustainability, trends, urban bus service.
\end{abstract}

\section{INTRODUCTION}

The word 'crisis' can be used to describe problems in urban public transport by bus in many developing countries. The term seems to be appropriate for cities of the developing world where mobility impacts such as congestion, traffic fatalities and injuries, environmental pollution and noise are severe when compared to cities in developed countries.

Developing countries have several factors in common that contribute to the severity of their transport problems. Overall, population growth and increasing urbanization have led to rapid growth of large cities, which overwhelm travel demand. Public sector finances, in general, are so limited that funding for transport improvements is inadequate [1]. Moreover, facilities for pedestrians and cyclists are almost non-existent in most cities, thus forcing them to share crowded roads and streets with rapidly moving motor vehicles. Another issue is that the overall low per-capita incomes in developing countries are compounded by extreme income inequality. In some developing countries, the wealthiest tenth of the population typically earns over half of the total national income [2].

This article aims to address the crisis of public transport by bus in developing countries and to analyse the evolution of demand for urban bus service in Brazil, showing the reasons for the decline over the years, the current situation and future trends. it's the conclusions and recommendations from this paper may help the developing countries decision makers' to propose resolutions and future improvements.

\section{CHARACTERISTICS OF THE CRISIS OF PUBLIC TRANSPORT BY BUS IN DEVELOPING COUNTRIES}

In developing countries located in Latin America, Africa and Asia, public transport by bus has been showing characteristics that can be compared to a crisis [1,3]. Most of their bus systems suffer from issues, which can vary from one country to another, according to the nature and extent of transport problems, such as:

- rapid growth;

- low incomes; 
- extreme inequality;

- conditions of local demand that far exceed the capacity of facilities;

- unplanned, haphazard development at the suburban fringe without adequate infrastructure;

- rapidly increasing ownership and use of private cars and motorcycles;

- incompatibility between urban structure and increased motorization;

- inadequate roadway accommodations for buses and non-motorized transport;

- extremely congested roads with an incompatible mix of both motorized and non-motorized vehicles travelling at widely different speeds;

- lack of adequate road maintenance;

- lack of a clear and comprehensive policy on public transport;

- limited regulatory/institutional effectiveness;

- overcrowded, uncomfortable, undependable, slow, inefficient and dangerous public transport;

- primitive or non-existent traffic control and management;

- extremely high and rapidly rising traffic fatalities, especially among pedestrians and motorcyclists;

- extremely high levels of transport-related pollution, noise and other environmental impacts, especially in large cities.

Urban population is expanding by more than $6 \%$ annually in most developing countries. Within one generation over one half of the developing world's population will live in cities. This implies an increase of 2 billion, equal to the present day total urban population of developing countries [4]. World's urban population was around $10 \%$ in 1900 , nearly $50 \%$ in 2005 and will rise to $70 \%$ in the next 20-30 years if the present trend continues [5]. The number of megacities (cities with over 10 million inhabitants) is expected to double, with three quarters in developing countries [4].

With the continuous increase of people living in urban areas, the world will face many problems to provide effective transport, mainly in the developing world. Much growth added to the absence of policies on land use and economic development will likely led to urban sprawl, which disturbs public transport service and reduces accessibility to employment and urban facilities for the poor [6]. The declining density associated with sprawl raises the price of public transport and also increases travel time and distance [7]. Surveys of commuters in Mexico City have shown that 20\% of workers spend more than 3 hours in travelling to and from work each day, and $10 \%$ spend more than 5 hours [4].

Though the majority of vehicles are in the developed world, developing countries have been experiencing rapid growth in the number of road vehicles. Motor vehicle ownership and usage are growing even faster than population, with vehicle ownership growth rates of 15-20\% per year [4]. In China, automobiles are increasing at $25 \%$ a year [3]. In Korea, there was an annual increase averaging 24\% for 7 years following 1985. Between 1975 and 1995 the number of passenger cars per thousand inhabitants doubled in Mexico, tripled in Botswana and Malaysia and quintupled in Ecuador. In Bangkok, a sevenfold increase in the number of road vehicles between 1970 and 1990 has contributed to some of the worst urban traffic conditions in the world, with peak hour traffic speeds as low as $3 \mathrm{~km} / \mathrm{h}[8]$.

Some [9] have expressed their concerns over the rapid growth of car ownership in China, a situation that is becoming unsustainable. Besides this, in the majority of Chinese cities the cultural use of bicycles is actually being discouraged by measures giving priority to automobiles and neglect for non-motorized infrastructure [10]. Some Chinese cities have even banned the use of bicycles in certain zones [9].

Particularly in developing countries, there has been a rapid growth of motorized two-wheelers that are faster in jams than private vehicles, bicycles or buses. The two-wheelers are so inexpensive 
compared to the other options that even the relatively poor can afford them. A recent study in Delhi, India, pointed that with an average per capita income of less than $\$ 2,000$ per year, over $80 \%$ of households have motorized vehicles, mostly two-wheelers [4]. In India, there was an extremely rapid growth of motorcycle ownership, which increased 16-fold between 1981 and 2002 [1].

While the use of private vehicles is constantly increasing in developing countries, the same cannot be said for public transport. In many developing countries the use of public transport is declining at a fairly constant rate and being replaced by individual transport [11].

Traffic conditions in Bangkok (Thailand) deteriorated rapidly in recent years. In 2006, the average travel speed on main roads reached $4.8 \mathrm{~km} / \mathrm{h}$. The principal causes of this deterioration are the rapid growth and unrestrained use of private vehicles, a poorly developed road network, lack of investment in the current mass transit system, poor planning and government indecision over an appropriate transport policy [8]. In India, buses get stuck regularly on congested roadways, which present an average of $6-10 \mathrm{~km} / \mathrm{h}$ in many large cities [1].

In most developing countries, the burden of transport expenditure on poor people is very high, excluding them from work and social services. Many Indians cannot afford the low fares on public transport since fourth of India's population live in poverty. Thus, they are forced to walk or cycle increasingly long distances [1]. A survey of pavement dwellers in Chennai, India, has shown that $59 \%$ walked to work at no cost [4]. In the poorest areas of Kuala Lumpur, almost $40 \%$ of journeys are made on foot [8].

\section{A CASE STUDY FROM BRAZIL}

\subsection{Brazil's history of public transport by bus}

In the 1940s and 1950s buses were operated by autonomous drivers from informal sector without fixed route [12]. At that time, rapid growth of cities due to migration of rural people could be observed, especially the suburbs, typically composed by low-income people and potential users of public transport. Simultaneously, streetcar systems began to fail to meet growing areas in cities because lack of investment. These new regions began to be attended by bus operators which could offer characteristics of flexibility, speed and service door to door better adapted to a diffuse and random urbanization [13]. Thus, structured around the family unit that forms the basis upon which transport by bus in Brazil developed and consolidated, bus operators were responsible by increasing offer of transport and becoming an integral part of the transport scenario in Brazil.

The bus system was effectively consolidated from the 1960s and 1970s, when services appeared without a defined path, collecting and leaving passengers near their homes. While the networks of streetcars were put aside, municipalities began to create public transport companies to impose regulatory policies to bus operators, which were forced to fuse between them and standardize types of vehicles. It led to the beginning of modern and formal bus companies' provision. The 1990s saw the opening of the Brazilian economy and liberalization of vehicles importations, which contributed to the proliferation of unregulated forms of public transport and encouraged the increase of private vehicles [13, 14].

Brazil's 1988 Constitution established public transport by bus as a public service [15]. By this legal concept, it is part of the competence of the Public Administration to run public service, but its execution may be delegated by a concession contract or permission, provided that a formal tendering procedure is organised in order to select the operator [16]. It has been very difficult to implement because of insufficient institutional coordination, human, technical and financial capacity among transport organizations. It still needs strict regulations, performance standards and overall coordination to ensure an integrated network of services. 


\subsection{Crisis of public transport by bus in Brazil}

Urban public transport is responsible for carrying 59 million passengers a day in Brazil, over $60 \%$ of mechanized trips in the country's cities. The bus segment serves $92 \%$ of demand for collective transport, generating approximately 500 thousand direct jobs, with a fleet of 95 thousand vehicles [17]. The sector's annual turnover is over $\mathrm{R} \$ 21$ billion and has a direct influence on other economic sectors, as a basic input in the production and consumption of goods and services, being a structuring element for urban activities, with a strong effect on the quality of life in cities.

According to the Brazilian Institute of Geography and Statistics, the official census bureau, in 2011, Brazilian population exceeded 190.7 million people. United Nations Population Fund expects this number to be 218.5 million people by 2050 [18].

Car ownership in Brazil is about 150 vehicles per 1,000 inhabitants, which represents more than three times the average of Latin America [19]. The index of private motorization in Brazilian cities increased from 9 vehicles per 100 inhabitants in 1980 to nearly 17 in 2000 [20]. According to the Brazilian National Association of Motor Vehicles Manufacturers, the production of vehicles has grown by $135 \%$ in 2009 compared to 1999 [21].

On other hand, the demand for public transport in Brazil is facing one of the worst crises in its history, a crisis that started over 16 years ago, characterized by a steady fall in demand and productivity. Figure 1 shows that the number of passengers carried by urban buses fell significantly between 1995 and 2004 by 35\% in Brazilian cities. From 2005 this trend began to recover slightly, but in 2008 it began to fall again. Overall, between 1995 and 2009 the demand fell by $30 \%$.

The automobile industry has been receiving strong government incentives, both directly and indirectly, among them various tax breaks. The Brazilian automotive industry has been in a phase of almost uninterrupted expansion since 1992, with emphasis on production of economical cars, financed in up to 36 months, in a regime of economic stability, spurring instalment sales. This has produced a large increase in the number of car owners in the lower-middle class, where use of public transport is concentrated.

According to National Traffic Department, Brazilian fleet jumped from 24 to 61 million units between 1998 and 2010, registering a growth of $170 \%$ over a period of 12 years. The use of motorcycles has also risen in recent years, reaching in 2010 almost half the number of cars existent in Brazil [23].

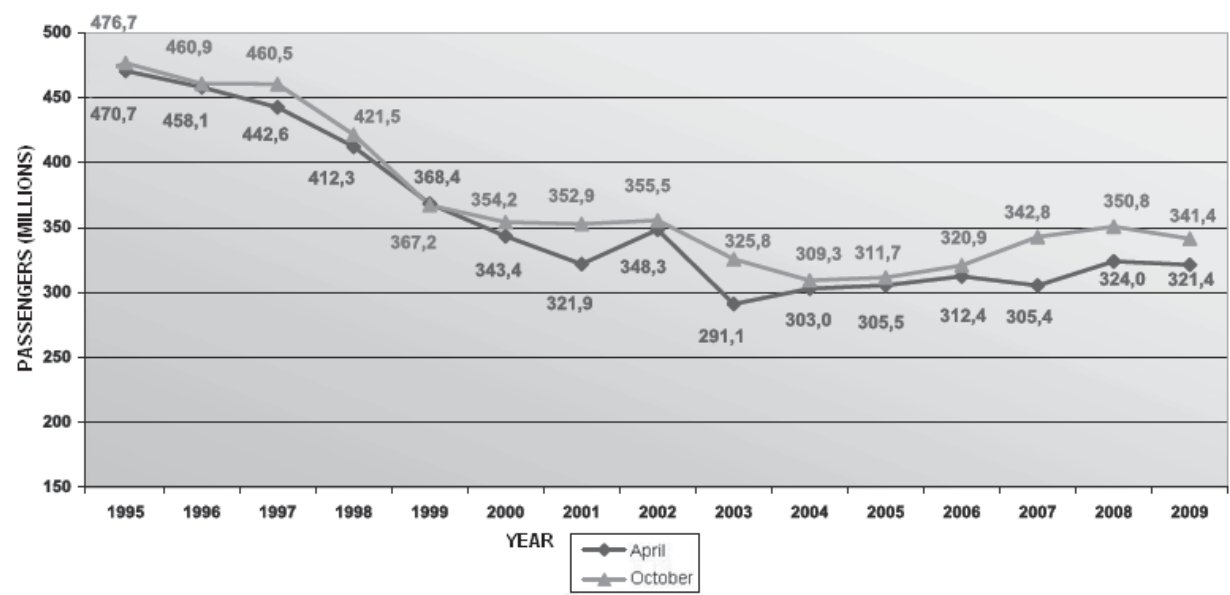

Figure 1: Passengers carried per month by bus systems in Brazilian cities (adapted from [22]). 
The lack of investments in public transport to overcome traffic congestion translates into lower speeds and increases operating costs to maintain the same level of service. A study coordinated by Brazilian Institute for Applied Economic Research (Instituto de Pesquisa Econômica Aplicada IPEA) in partnership with Brazilian Public Transport Association (Associação Nacional de Transportes Públicos - ANTP) entitled "Reduction of Wasted Urban Costs through Improved Public Transport" in 1997 found average speeds in the main corridors of 10 Brazilian cities between 14 and $22 \mathrm{~km} / \mathrm{h}$, with a minimum in São Paulo (12 km/h) and maximum in Brasília ( $27 \mathrm{~km} / \mathrm{h})$. According to the study, the severe traffic jams in these cities imply an increase in the bus fleet of 4,800 (evening peak), corresponding to $16 \%$ of the total fleet in operation. Under these conditions, because of congestion and the added fuel consumption, the increased fleet raised the operating costs by $\mathrm{R} \$ 474$ million a year, meaning a proportional cost increase of 10\% in Rio de Janeiro and 16\% in São Paulo. The exceeding annual fuel consumption due to traffic jams was calculated as 14.1 million litres of diesel oil [24].

In recent years, high fares have been pointed as the main reason for the declining bus ridership, besides contributing to other social problems. But the other reasons also should be considered. There is a serious problem of quality and efficiency that acts to reduce the competitiveness of public transport. Inadequate supply to meet users' needs, insufficient technological development and innovation and the need for heavy investments to meet the high demand for infrastructure are some of the problems.

Another serious operational problem is the proliferation of informal transport (pirate transport), which siphons off passengers from the legitimate system and aggravates traffic congestion. It also causes disorganization of the overall transport system and increases accidents, not to mention the failure to serve people entitled to ride free or at reduced fares. Until the start of the 1990s, informal transport was not a large factor. But in 1995 this changed with economic stabilization that facilitated vehicle purchase through time payments and the strong entrance of vans in the market caused by the arrival of more carmakers offering these models (previously limited basically to Volkswagen vans).

Another factor was increased unemployment due the downsizing effects of economic opening on formerly protected domestic industries. Many laid-off workers used their severance benefits to purchase or make down payments on vans as a means to support themselves. This was a big factor in the steep decline in passengers carried by legitimate bus operators as of 1996. This created a component competing with transport systems conceived and organized to operate under rigid government control. Mainly because of the ability to evade much of the tax burden, there were even air conditioned vans charging lower fares than similarly equipped buses and offering quicker trips because of fewer stops.

In 2003, signs began to appear of possible recovery in the urban and metropolitan bus sector, which had been passing through an unprecedented crisis along the previous 8 years. However, the stabilization in number of passengers carried by bus in the main Brazilian cities at around 350 million between 2000 and 2002 was $26 \%$ lower than in 1995, when the index reached 476 million passengers a month (Fig. 1). A contributing factor to this stabilization was the frequent increases in the price of gasoline, which contained the use of cars, especially by social classes with less purchasing power (the classes most benefited by the economic stabilization, through the ability to buy individual vehicles). Besides this, government efforts to suppress illegal transport became more effective in most cities, causing less competition for passengers.

In 2004, the number of passengers carried was 15\% lower than in 2002, and in 2005 demand in the sector was 36\% below its best performance (1995) in the period after 1994's Real Plan currency stabilization, despite being slightly higher than in 2004. The economic recovery starting in 2004 and various measures to improve transport systems contributed to stabilize the situation. The investments in some cities, as São Paulo, in infrastructure, fleets and fare payment equipment made the entire system more 
attractive through increased operating speed and reliability. Another important factor was allowing passengers to use the system for any trip for a period of 2 hours at a single integrated fare, no matter how many transfers. The result was a rise in total passengers of over $50 \%$ and paying passengers of $5 \%$. Although this latter figure may seem small, it represents a change in the trend of decline of paying customers of the previous 9 years and is considered a sign of renewed vitality of the system.

Nationwide, the volume of passengers carried from 2005 to 2008 was higher than 2004, indicating a stability trend, but not enough to recover the falling demand trend in the preceding years. It could be explained by the recovery of economic activity since 2006, beyond other various measures for improvement of transport networks adopted in main Brazilian cities. New technology provided prospects for renewed expansion, particularly through Intelligent Transport Systems (ITS), including use of electronic fare cards and card readers, on-the-road fleet monitoring. Indeed, electronic fare systems are spreading in Brazilian cities, having been set up in $69 \%$ of cities with over 100 thousand inhabitants [17].

The data of 2009 compared to 2008 show new decline in demand of about $2 \%$, which shows that the crisis persists. Indeed, based on the national average, public transport by bus carried $30 \%$ fewer passengers in 2009 than in 1995, which makes no sense considering the population increase over these years. One of the main explanations for the continuity of the crisis over the past 16 years is the high price of fares, which has steadily risen.

Data from IPEA confirm that over 37 million Brazilians are unable to use public transport regularly because they simply cannot afford the fare [17]. A survey conducted by the Institute for Transport Development and Information [25] reveals that the mobility of the poor population in large Brazilian cities, measured by the average number of daily trips per person, is very low, indicating serious problems of access to jobs and opportunities for leisure and basic social services. These precarious mobility conditions are a major barrier to overcoming poverty and social exclusion for the roughly $45 \%$ of the Brazilian urban population with household incomes under three times the minimum monthly wage.

Currently, $20 \%$ of public transport passengers use school passes, with discounts ranging from 50 to $100 \%$, and the elderly (60 and above), who are entitled to free passage, represent another $6 \%$ of the total riders [26]. The benefits granted to both these groups to a certain extent represent a hidden subsidy from the poor to the better off, since a portion of the elderly and students fall in the middle classes and are being subsidized by full-fare paying workers in the informal sector, who generally have meagre earnings.

Unlike in developed countries, where society transfers resources to public transport to reduce its operating cost, in Brazil the opposite occurs, through the taxes levied on the fares of paying passengers. Over $30 \%$ of urban transport fares go to pay federal, state and municipal taxes and social charges, as shown in Table 1.

According to Metropolitan Company of Urban Transport, a company controlled by the São Paulo State Government, besides the increase in the price of diesel oil of $86 \%$ between 2001 and 2003, in the same period, the price of tires rose $77 \%$ and the minimum monthly wage increased only $58 \%$ [27]. From 2001 to 2007, diesel oil increased in price by $140 \%$ and tires by $100 \%$ [17]. Historically, about $10 \%$ of bus companies' overhead has been for fuel, but with the succession of price increases of this input, this figure has risen to $30 \%$ [28].

Therefore, urban bus service has been experiencing a serious crisis because of declining ridership, unfair competition from informal transport, cost increases outpacing inflation, a high tax burden, the requirement to grant fare discounts and waivers without any government funding or tax breaks and especially because of the inefficiency of road systems. All these costs are passed through to paying users (except for the declining portion who receive subsidies from their employers). 
Table 1: Tax burden on mass transport services (adapted from [17]).

Direct

\begin{tabular}{ll}
\hline Federal taxes & $\begin{array}{l}3.65 \% \\
8 \%\end{array}$ \\
Municipal taxes and fees & $10.28 \%$ \\
\hline Social charges & \\
\hline Indirect & $4.5 \%$ \\
\hline ICMS on diesel oil & $1.2 \%$ \\
ICMS on vehicles & $3.75 \%$ \\
CIDE and PIS/Cofins on diesel oil & $31.38 \%$ \\
Total &
\end{tabular}

Note: ICMS is state value-added tax. CIDE is the "Contribution for Intervention in the Economic Domain", a federal industry-specific levy to raise funding for research to benefit the taxed industry. PIS/Cofins are two social contributions to fund social security. Contributions are taxes whose revenues are earmarked for specific purposes rather than going into the general fund.

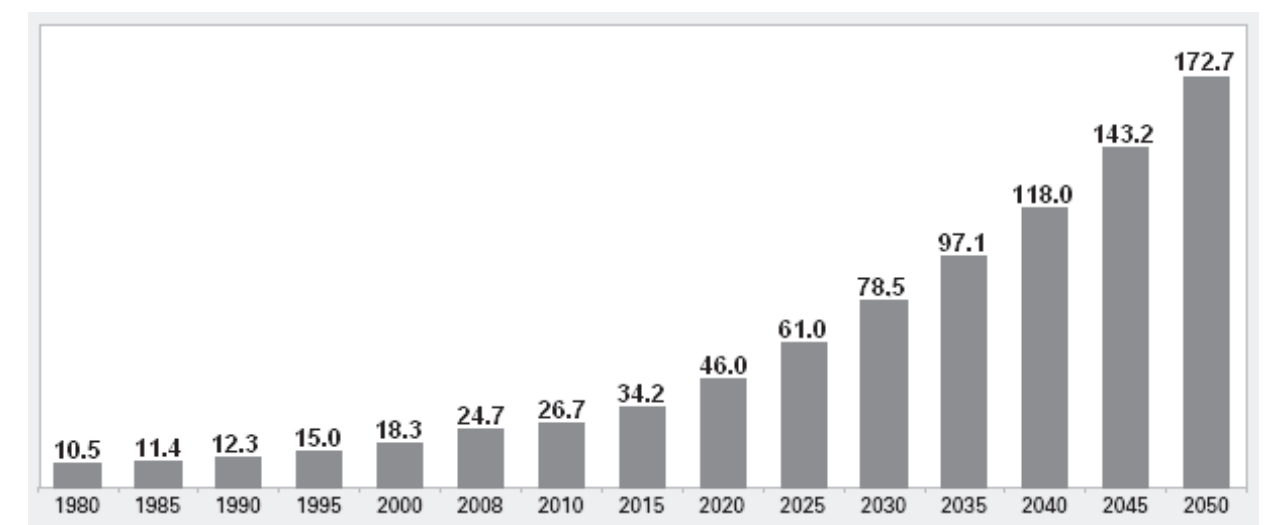

Figure 2: Evolution of the aging index of the Brazilian population $\{[\mathrm{POP}(65+) / \mathrm{POP}(0-14)] \times 100\}$ (adapted from [30]).

\section{BRAZIL'S BUS SERVICE TRENDS INTERRELATED WITH SOCIOECONOMIC CHARACTERISTICS}

The aging of the Brazilian population is still in its initial stages, but is irreversible based on demographic trends. Between 1980 and 2050 the population of young people (0-14 years of age) will fall to less than half the overall population and the elderly (65 and over) will rise fourfold [29]. In 2000, there were 1.5 million people aged 80 years and older, but in 2050 this figure is projected to rise to 13.7 million [30].

According to the 2007 National Household Survey (Pesquisa Nacional por Amostra de Domicílio - PNAD) [31], in 2006 Brazilian population continued to age at the same pace as in the previous few surveys, with the elderly contingent growing faster than the number of people in all younger age ranges. This graying of the population has particular bearing on the continuing feasibility of the rules entitling the elderly to ride public transport for free.

The birth rate has been falling in Brazil in recent years because of transformations in society and the family, as has been occurring in many other countries as well. Figure 2 shows the aging process 
of the Brazilian population. In 2000, for each 100 children, $0-14$ years old, there were 18.3 elderly people, 65 or older. In 2050, this ratio is projected to reach 172.7. This trend deserves special attention by policymakers because of the revenue effects, it will have due to the free fare rule for the elderly since a considerable number of people ageing is growing every year.

The effect of a steadily aging population will progressively reduce the number of paying passengers, which may aggravate current social exclusion and poverty cited on this article. However, this can be partly offset by the smaller number of school-age children entitled to ride free or at reduced.

The economics of the transport sector is very sensitive to the purchasing power of the middle and lower-income segments of the population. Social classes are classified in Brazil from A to E, with A being rich and $\mathrm{E}$ poor (below the official poverty line regarding per capita household income). Currently classes D (from 2 to 4 minimum monthly wage) and E (under 2 minimum monthly wage) are proportionally underrepresented among bus users. The main reasons for the low mobility are the rise in fares vis-à-vis the variation in income of the population and inadequate supply in relation to the needs of the lower classes. Figure 3 shows the evolution of the average bus fares, the inflation and the number of passengers carried according to two different sources in Brazil's main cities. It can be seen that the bus fare has been increasing higher than inflation, while in contrary the number of paying carried passengers has shown a declining tendency and stabilization in recent years.

In the period from January 1995 to December 2002, the average bus fare in Brazil's largest cities rose $25 \%$ more than inflation, measured by the General Price Index (IGP-DI) [26]. Besides that, between 1995 and 2008, bus fare in Brazil rose 60\% more than National Consumer Price Index (INPC) [33]. In turn, average income did not keep pace with this climb, accentuating the difficulty of using mass transit.

Figure 4 shows that between 1995 and 2003 a loss of purchasing power occurred in the minimum monthly wage related to public transport, presenting a strong relationship with the fall in the volume of paying passengers of this period [32]. However, since 2003 there is reversal of the declining trend in passenger volumes caused by the recovery of purchasing power of the minimum wage and by the fall in unemployment. As can be seen in Fig. 5, the unemployment rate fell in Brazil from $13.1 \%$ of the labour force in 2003 to $6.7 \%$ in 2010, reflecting the heating up of demand for urban transport that after 2004 started to stabilize.

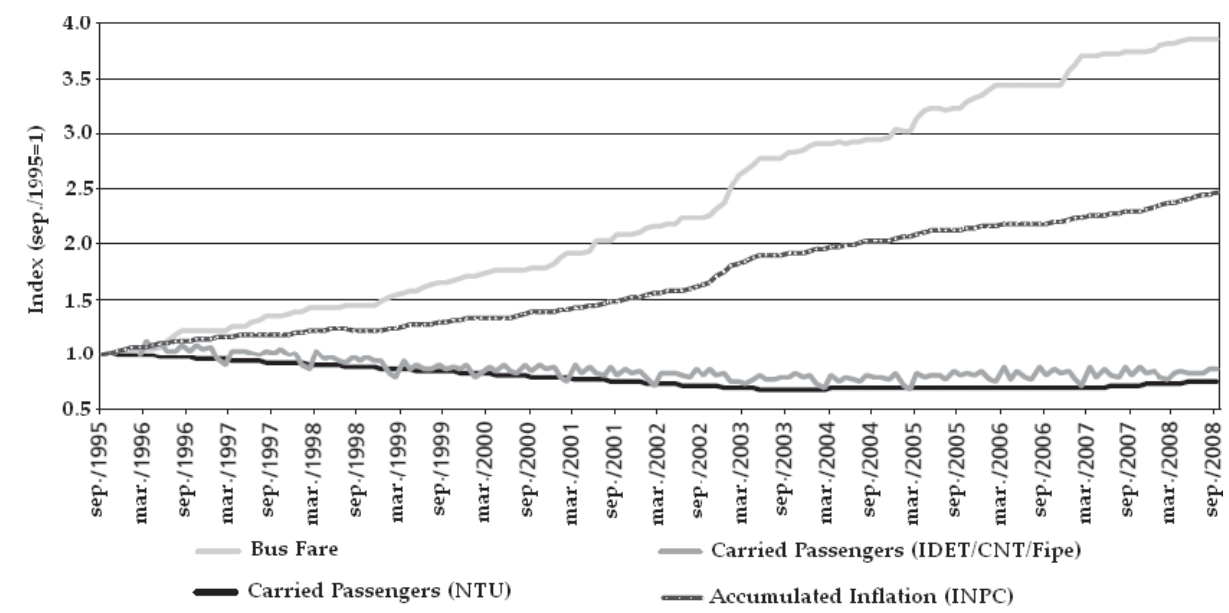

Figure 3: Evolution of urban bus fares, inflation (INPC) and paying carried passengers [32]. 


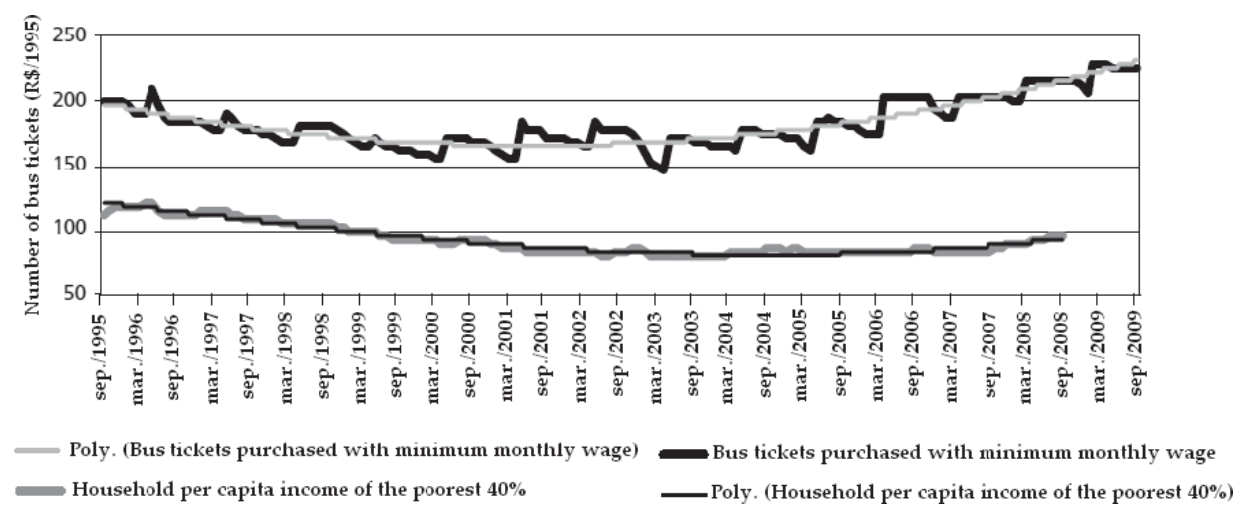

Figure 4: Number of bus tickets purchased with a minimum monthly wage and household income per capita of $40 \%$ poorest [32].

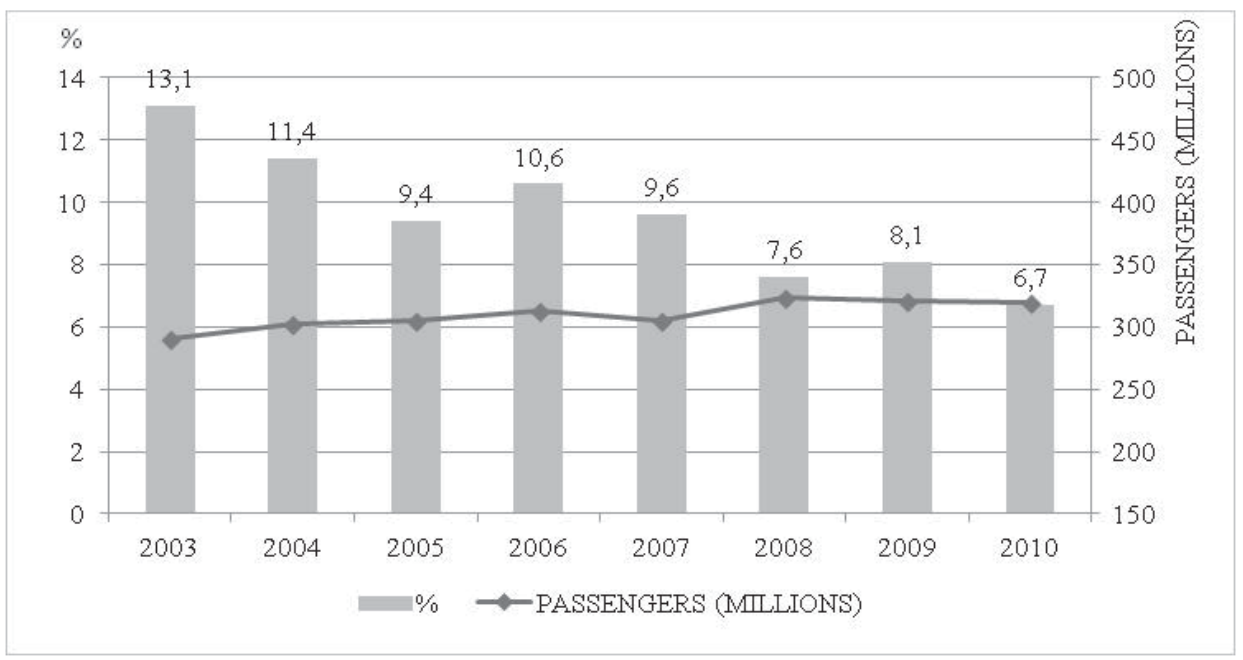

Figure 5: Comparison of unemployment rate of Brazil population from 2003 to August 2010 with passengers carried per month by bus systems in Brazilian cities (adapted from [22,34]).

The growth in the earnings among the lower classes contributes to a desconcentration of income in Brazil, but it is not enough to cause a significant impact on inequality of earnings. The Gini index, an inequality measure, went from 0.593 in 2001 to 0.518 in 2009 . The lower the index is, the more equal the income distribution, with zero at one extreme (perfectly equal distribution) and 1 at the other extreme. Although the yearly PNADs have been registering reductions in the Gini index, the figures for 2009 show that the bottom $10 \%$ of the occupied population in terms of earnings only gained $1.2 \%$ of total national wage income, while the top $10 \%$ of workers concentrated $42.5 \%$ of total earnings. This was only a small change compared to the preceding year, when the respective percentages were $1.2 \%$ and $42.7 \%$ [31].

Currently, Brazilian Government is trying to change the scenario as the recent attempt of valuation policy of minimum monthly wage until 2015 shows. According to this act, the adjustment of the 


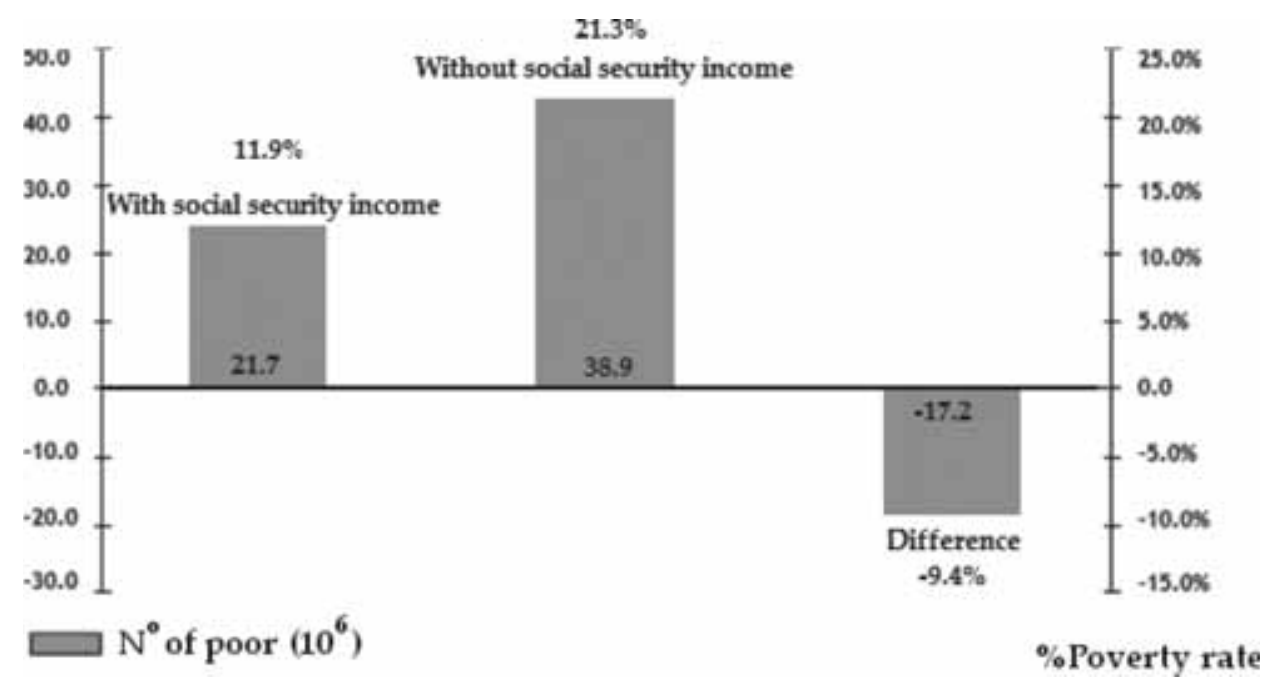

Figure 6: Number and rate of extremely poor people (adapted from [35]).

minimum monthly wage corresponds to the sum of the previous year's inflation with the rate of economic growth from 2 years before. It tends to raise particularly the earnings of workers in the lower classes.

Social security programs play an important role in reducing the extreme poverty of a large number of Brazilians. Transfers (pensions, assistance and other programs such as maternity and poor family benefits) held decisively to diminish poverty in the country. Figure 6 shows that the number of people in extreme poverty today is 21.7 million throughout the country (defined as people with per capita monthly income under one-fourth the minimum monthly wage). However, if the household income from social security and assistance programs were removed, the number of extremely poor people would rise to 38.9 million. In other words, social security programs allow 17.2 million people to rise above abject poverty, a percentage reduction of $44.1 \%$. The Bolsa Família Program (an income transfer program to poor families who keep their kids in school) also has helped reducing inequality, through improvements on two fronts: improved labour income distribution and income transfers from the richer to the poorer [35].

Brazilian Government is also making efforts to improve Bolsa Família Program and recently signed a decree that establishes an average adjustment of $19 \%$, though amounts paid between the ages of $0-15$ years may reach up to $45 \%$. This readjustment is expected to benefit 13 million families - about 50 million people with per capita monthly income up to $\mathrm{R} \$ 140$. The adjusted value represents an average increase of $8.7 \%$ over inflation for the period from September 2009 to March 2011.

Another important trend is shown in Fig. 7, which presents the evolution of gasoline and diesel prices in Brazil. Brazilian's fuel pricing policy currently generates perverse results in the environmental standpoint and penalizes people on the lower economic rungs who depend heavily on bus service in cities. Since 2002, diesel oil ceased being cross-subsidized by the price of gasoline. The federal government's policy on fuels began to be based on the variation in the exchange rate with the dollar and the international price of oil.

An increase in the price of gasoline would enable a reduction of the price of diesel sold to bus companies, besides discouraging the trips taken by cars, thus easing the volume of vehicles on the roads and increasing the speed of bus services. Adjustments in the tax burden on diesel or renewed 


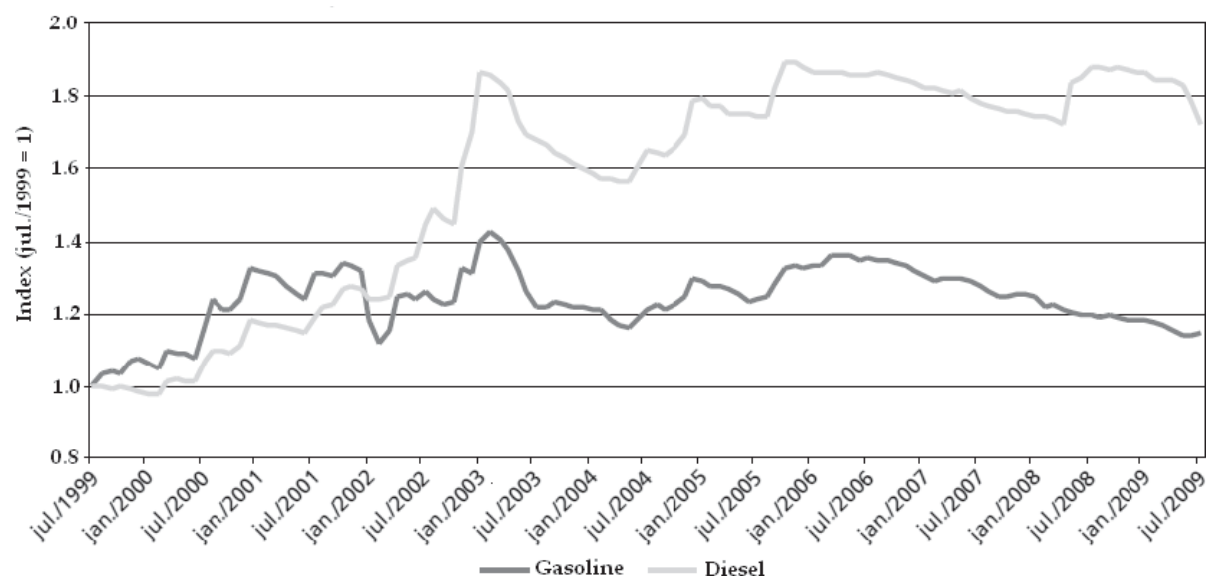

Figure 7: Evolution of gasoline and diesel prices [32].

cross-subsidies from gasoline would make this important social measure possible. An increase of $4.5 \%$ in the price of gasoline would be enough to allow a 50\% reduction in the price of diesel to bus companies [17]. From 2002 to 2004, according to data from the Inter-Union Department of Statistics and Socioeconomic Studies (DIEESE, a think tank associated with the labour union movement), while the cost of living rose $33.24 \%$, the price of diesel oil went up to $94.55 \%$ and of gasoline to $27.59 \%$ [17]. This is glaring evidence that fuel price policies have been favouring individual vehicles, when the opposite should be the case.

\section{CONCLUSIONS}

This article discussed the issues of public transport by bus in developing countries and concluded that many of them are suffering very similar problems characterizing a crisis. The rapid growth of inhabitants of developing countries well-marked by the absence of policies on land use and economic development has generated a correspondingly rapid growth in travel demand besides issues such as urban sprawl, overwhelming its limited transport infrastructure. Also, these countries are unable to cope with the constantly growing motorization since deficient public policies on mass transit and economic growth have been causing a dramatic increase in private transport and decrease of use of public transport, which is resulting in alarming levels of congestion, air pollution, noise and traffic danger.

Planning is necessary in these countries to make bus systems faster and cheaper, besides to enable them to compete effectively with private transport, which is completely inefficient from an energy standpoint. Public funding, fuels' prices, investments in infrastructure and policies to restrict use of private cars will define the competitiveness of public transport.

Brazil is undergoing a crisis in public transport by bus since 1995, having lost $30 \%$ of the demand until the present day. This crisis is not worse because of the falling rate of unemployment and increasing per capita income. Even so, this article revealed that effectively almost nothing is being done by the Brazilian Government to prioritize public transport. Regarding infrastructure little has been done, though BRT systems have been conceived to the World Cup host cities.

The absence of policies that promote the reduction of prices of public transport fares, which have been increasing more than inflation during the last 16 years, is visible. It was also pointed that in periods when per capita income remains stable or grows, use tends to rise, and the opposite happens 
when income falls, as people seek cheaper alternatives to move around. People with lower incomes are the group that most depends on mass transit to move around in cities, and there is an urgent need for changes in the sector's structure to lower fares and improve service to bring these people back to the system.

Since urban public transport is an essential public service mainly used by lower income people, Brazilian Government needs to impose differentiated tax treatment, by lowering direct taxes on fare revenues and indirect ones on the main inputs, such as diesel oil and buses. Another important factor to reduce operating costs is to provide public funding to defray the cost of free and reduced-fare passengers.

There is also a need to lower the burden of social security contributions on Brazilian bus companies' payrolls. Since the sector is labour intensive, this would have a large impact on the cost structure. Another measure would be to reduce the PIS and Cofins rates on public transport revenues, besides cutting the municipal service tax (ISS) rates on those revenues.

Another issue revealed by this article highlights that in Brazil the policy of providing free transport to students and the elderly, without spreading the cost fairly to all society through public funding (by the federal, state and/or local governments), winds up unfairly raising of the costs of paying passengers, made up disproportionately of lower income people who can least afford it. Besides that, it was pointed that the aging trend of the Brazilian population may worsen this problem.

More important than delineating measures for recovery of demand for urban public transport, as done in this article, it is left to experts in the field to define ways that can raise the awareness of authorities at all levels of government of the importance of establishing priority for collective over individual transport and the need to adopt measures to benefit the public at large instead of individuals. This would be essential not only to Brazil but for the entire world in general. Since climate changes caused by global warming is an undeniable fact nowadays, it is important to emphasize that massive transport vehicles contribute to the improvement of the quality of the urban environment by reduction of congestion and noise, aside from less emission of local pollutants and greenhouse gases than emitted by private vehicles.

The considerations made in this section referred basically to the Brazilian situation. However, the Brazilian reality and the policies suggested to deal with the public transport crisis are also applicable to other developing countries realities. Justifying this statement, it should be noted that in many developing countries:

- the use of public transport is declining at a fairly constant rate and being replaced by individual transport, such as in Thailand, Argentina, India, Mexico, Korea and China [11];

- the public transport sector is inadequate, uncomfortable and inefficient, offering slow speeds, such as in Africa, India, Thailand, Mexico, China, Malaysia and Indonesia [1, 4, 7, 8];

- the public transport sector leads to social exclusion due population incapacity to high fare rates such as in India [1, 4] and Malaysia [8];

- motor vehicle ownership and use are growing even faster than population, such as in India, Africa, China, Chile, Mexico, Korea, Thailand, Costa Rica, Syria and Taiwan [1, 3 ,7];

- motorized two-wheelers ownership and use are growing since they are faster in jams than buses, such as in Vietnam, Indonesia and India [1, 4];

- the public transport sector is responsible for high levels of pollutant emissions, such as in India, Chile, Thailand and Africa [1, 4, 7];

- located in Latin America, Africa and Asia, public transport by bus has been showing characteristics that can be understood as a crisis, which presents similar characteristics and reasons $[1,3]$. 


\section{REFERENCES}

[1] Pucher, J., Korattyswaropam, N., Mittal, N. \& Ittyerah, N., Urban transport crisis in Indian. Transport Policy, 12, pp.185-198, 2005. doi: http://dx.doi.org/10.1016/j.tranpol.2005.02.008

[2] Vasconcellos, E., Urban Transport, Environment and Equity: The Case for Developing Countries, Earthscan Press: London, England, 2001.

[3] Gakenheimer, R., Urban mobility in the developing world. Transportation Research Part A, 33, pp. 671-689, 1999. doi: http://dx.doi.org/10.1016/S0965-8564(99)00005-1

[4] World Bank, Cities on the Move: a World Bank Urban Transport Strategy Review. Washington, DC, 2005.

[5] Worldwatch Institute, State of the World 2005: Redefining Global, W. W. Norton \& Company: New York, 2005.

[6] Aworemi, J.R., Oyedokun, J.A., Ajagbe, F.A. \& Ogunsiji, A.S., A study of the factors militating against public transport operations in Nigeria. International Journal of Sociology and Anthropology, 1(1), pp. 39-43, 2009.

[7] Kumar, A. \& Barrett, F., Stuck in Traffic: Urban Transport in Africa. Afric Infrastructure Country Diagnostic: World Bank, Washington, DC, 2008.

[8] Pacione, M., Urban Geography: A Global Perspective, 3rd edn., Routledge: Taylor \& Francis Group: New York, 2009.

[9] Schipper, L. \& Ng, W., Urban Transport Options in China: The Challenge to Choose, The WRI Center for Transport and Environment: EMBARQ, 2007.

[10] Hook, W., Does it make sense for China to motorize? Sustainable Transport, 14(2), pp. 19-29, 2002.

[11] Wright, L, The limits of technology: Achieving transport efficiency in developing nations. Proc. of the Annals of the International Conference for Renewable Energies, Bonn, Germany, 1-4 June, 2004, available at http://eprints.ucl.ac.uk/108/1/Lloyd_Wright,_Bonn,_Germany, _Transport_and_climate_change.pdf

[12] Costa, E.A.V.G., Estudo dos Constrangimentos Físicos e Mentais Sofridos pelos Motoristas de Ônibus Urbano da Cidade do Rio de Janeiro. Dissertação de Mestrado. Pontifícia Universidade Católica do Rio de Janeiro, Brazil, 2006.

[13] Brasileiro, A. \& Henry E., Secretaria de Viação, Fabricação e Promoção do Sistema Ônibus Brasileiro. Viação Ilimitada: Ônibus das Cidades Brasileiras, eds. A. Brasileiro, E. Henry and Turma, Brasília, Brazil, 1999,

[14] Ferreira, A., Características Competitivas no Mercado de Transporte Público Urbano no Rio de Janeiro: O Posicionamento dos Novos Entrantes. Tese de Doutorado em Engenharia de Transportes. Universidade Federal do Rio de Janeiro, Brazil, 2006.

[15] Brasil, Constituição da República Federativa do Brasil. Brasília, Brazil, 1988.

[16] Aragão, J.J.G., Santos, E M. \& Dourado, A.B.F., The Urban Public Transport Crisis in Brazil: Two Regulatory Reform Strategies and Some Questions to the World Bank. Proc. of the $7^{a}$ International Conference on Competition and Ownership in Land Passenger Transport (Thredbo 7). Cape Town, South Africa, 2001.

[17] NTU, Desoneração dos Custos das Tarifas do Transporte Público Urbano e de Característica Urbana. Associação Nacional das Empresas de Transportes Urbanos, Brazil, 2007, available at http://www.ntu.org.br/novosite/arquivos/DesoneracaoCustosTarifasAbr2007.pdf

[18] UNFPA, State of World Population. United Nations Population Fund, 2009, available at http:// www.unfpa.org/swp/

[19] IEA, World Energy Outlook - 2005, International Energy Agency: Paris, 2006. 
[20] NTU \& SEDU/PR, Prioridade para o Transporte Coletivo Urbano - Relatório Técnico. Associação Nacional das Empresas de Transportes Urbanos e Secretaria Especial de Desenvolvimento Urbano da Presidência da República, Brasília, Brazil, 2002.

[21] ANFAVEA, Anuário Estatístico da Associação Nacional dos Fabricantes de Veículos Automotores, Brazil, 2010.

[22] NTU, Anuário 2009-2010. Associação Nacional das Empresas de Transportes Urbanos, Brazil, 2010.

[23] DENATRAN, Dados do Registro Nacional de Acidentes e Estatísticas de Trânsito (RENAEST), Departamento Nacional de Trânsito: Brazil, 2011, availabale at http://www.vias-seguras.com /os_acidentes/estatisticas/estatisticas_nacionais/o_renaest

[24] ANTP \& IPEA, Redução das Deseconomias Urbanas com a Melhoria do Transporte Público no Brasil, Brazil, 1998.

[25] ITRANS, Mobilidade e Pobreza. Instituto de Desenvolvimento e Informação em Transporte. Final Report: Transportation Development and Information Institute, Brazil, 2004, available at http://www.itrans.org.br/upload/home/item/M\&P\%20Relatorio\%20Final\%20270304.pdf

[26] Ministério das Cidades, Proposta de Barateamento das Tarifas do Transporte Público Urbano. Secretaria Nacional de Transportes e da Mobilidade Urbana. Departamento de Cidadania e Inclusão Social, 2006, available at http://www.ntu.org.br/novosite/arquivos/BarateamentoTa rifas_SEMOB.pdf

[27] EMTU, Sistema Automático de Bilhetagem Eletrônica. Empresa Metropolitana de Transporte Urbano. São Paulo, Brazil, 2003.

[28] NTU, Anuário 2008-2009. Associação Nacional das Empresas de Transportes Urbanos, Brazil, 2009.

[29] Moreira, M.M., Determinantes Demográficos do Envelhecimento Brasileiro, Brazil, 2000, http://www.fundaj.gov.br/geral/textos\%20online/populacional/demografico.pdf

[30] IBGE, Projeção da População do Brasil por Sexo e Idade: 1980-2050 - Revisão 2008. Instituto Brasileiro de Geografia e Estatística, Brazil, 2008, available at http://www.ibge.gov.br/home /estatistica/populacao/projecao_da_populacao/2008/default.shtm

[31] IBGE, Pesquisa Nacional por Amostra de Domicílios. Síntese de Indicadores - 2009, Brazil, available at http://www.ibge.gov.br/home/estatistica/populacao/trabalhoerendimento /pnad2009/pnad_sintese_2009.pdf

[32] IPEA, Efeitos da Variação da Tarifa e da Renda da População sobre a Demanda de Transporte Público Coletivo Urbano no Brasil. Texto para Discussão 1595. Instituto de Pesquisa Econômica Aplicada, Brazil, 2011, available at http://www.ipea.gov.br/sites/000/2/publicacoes/tds /TD_1595_Web.pdf

[33] IPEA, Boletim Regional, Urbano e Ambiental - 03, december. Instituto de Pesquisa Econômica Aplicada, Brazil, 2009, available at http://www.ipea.gov.br/portal/images/stories /PDFs/100406_boletimregio3.pdf

[34] IBGE, Pesquisa Mensal de Emprego - Agosto, Brazil, 2010, available at http://www.ibge.gov. br/home/estatistica/indicadores/trabalhoerendimento/pme_nova/pme_201008pubCompleta.pdf

[35] IPEA, PNAD 2006. Primeiras Análises: Demografia, Educação, Trabalho, Previdência, Desigualdade de Renda e Pobreza. Instituto de Pesquisa Econômica Aplicada, Brazil, 2007, available at http://www.ipea.gov.br/sites/000/2/pdf_release/18Pnad_Primeiras _Analises_2006.pdf 